\title{
Biology of Pod Borer, Maruca vitrata (Geyer) Infesting Lablab Bean
}

\author{
K.G. Shinde, Kumud V. Naik"* P.P. Raut, V.S. Desai and S.K. Mehendale \\ Department of Agricultural Entomology, College of Agriculture, Dapoli, Dr. Balasaheb Sawant \\ Konkan Krishi Vidyapeeth, Dapoli, Ratnagiri District -415712 (M.S.), India \\ *Corresponding author
}

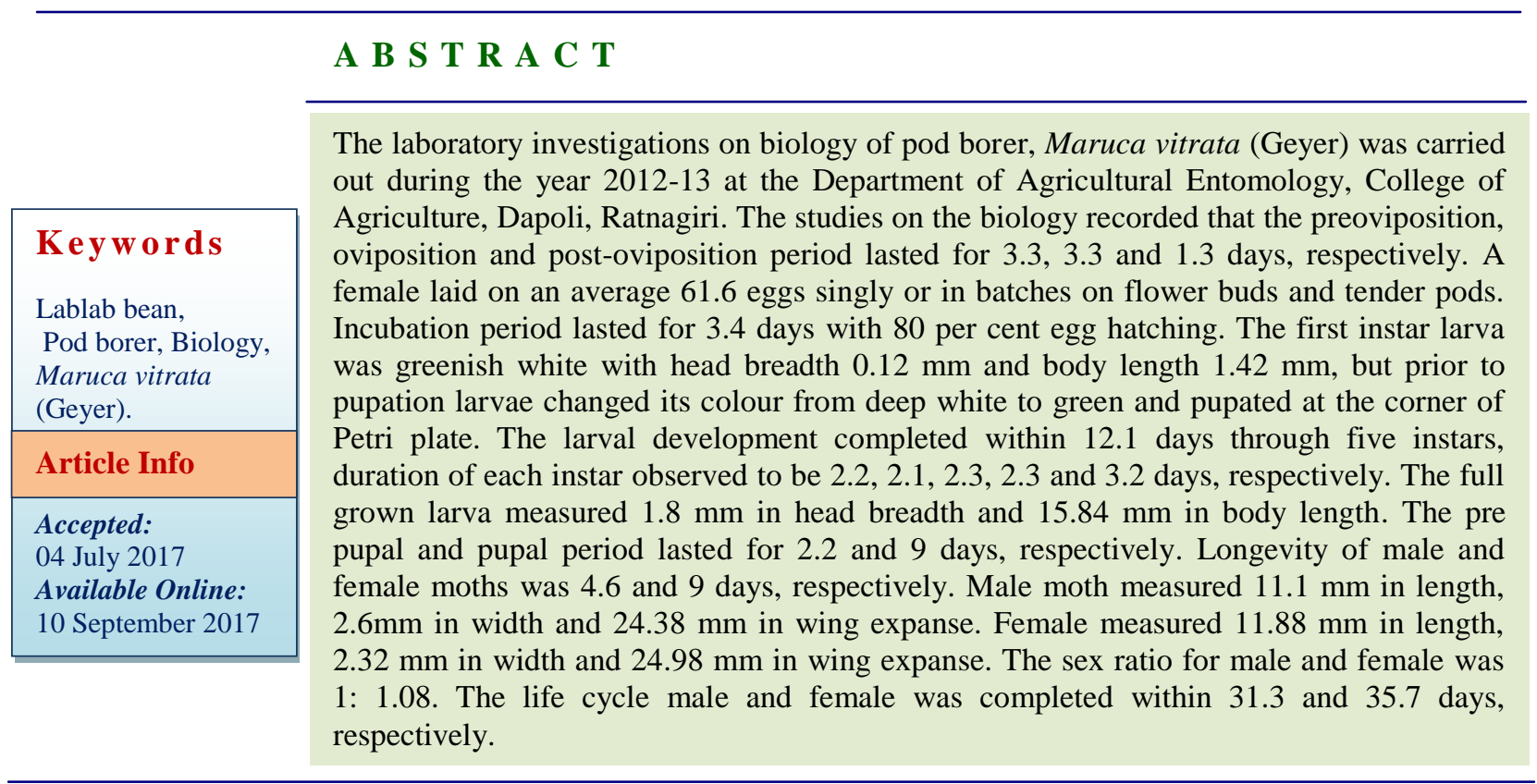

\section{Introduction}

The lablab bean, Lablab purpureus Linnaeus is an important pulse-cum-vegetable crop in India cultivated for its tender and mature pods, seeds and also for fodder. It is rich in nutritive value as it is a rich source of carbohydrate, minerals and vitamins, such as vitamin $\mathrm{A}$, vitamin $\mathrm{C}$, fat and fibers. The protein content of lablab bean is quite high varying from 20.00 to 28.00 per cent (Anonymous, 2012). The damage by insect pests is considered as one of the main impediments in stepping up the production of the crop.
A number of pests severely ravage the 2 buds, flowers and developing seeds of lablab bean crop.

In India, the total area under pulses was 23.63 million hectares with an annual production of 14.76 million tonnes (Anonymous, 2011a), while in Maharashtra annual production was 2.79 million tonnes (Anonymous, 2011b).

In Konkan, the total area under pulses was 88000 hectares with an annual production of 37 metric tonnes (Anonymous, 2011c). 
Among the various pests, pod borer complex comprising of Helicoverpa armigera (Hubner), Adisura atkinsoni (Moore), Maruca vitrata (Geyer), Etiella zinckenella (Treitschke), Cydia ptychora (Meyrick), Exelastis atomosa (Walshinghan), Sphenarches caffer (Zeller) and Lampides boeticus (Linnaeus) are of considerable importance causing 80 per cent pod damage (Katagihallimath and Siddappaji, 1962). Sucking pests like lablab bug, Coptosoma cribraria (Fabricius), Riptortus pedestris (Fabricius) and Nezara viridula (Linnaeus) occurred commonly and observed in large number throughout the cropping period.

The larvae of pod borer, $M$. vitrata are known to cause considerable damage to lablab bean attacking various parts viz., buds, flowers, pods and seeds. Its nature of damage is exhibited by weaving unopened buds and flowers. The larva further damages the reproductive parts of flower leading to poor pod setting and pod formation. In the later period of crop growth, it behaves as a pod borer and completes its larval and pupal development inside the pod. This leads to poor pod formation, reduction in grain yield as well as adverse effect on market value of green pods.

The lablab bean, locally called as 'wal' is one of the important pulse crops of Konkan region grown in the rabi season. It is severety infested by pod borer, M. vitrata. Since few years, considerable research work on biology of this pests has been done in abroad and India, but not from Konkan region of Maharashtra. Considering the importance of lablab bean and seriousness of pod borer, $M$. vitrata, the present investigation was planned and conducted.

\section{Materials and Methods}

The studies on biology of lablab bean pod borer, $M$. vitrata was carried out at the
Department of Agricultural Entomology, College of Agriculture, Dapoli under laboratory conditions from December, 2012 to February, 2013.

A brief account of techniques employed and material used in the present study is described below.

\section{Maintenance of culture}

The initial culture of pest was obtained by collecting larvae from Botany Farm, College of Agriculture, Dapoli, during the month of November. The larvae were reared in the glass jars (41 cm height and $30 \mathrm{~cm}$ diameter). Fresh buds of lablab bean were provided daily as food for larvae till pupation. Freshly formed pupae were kept individually in small sized plastic jar, the top of which was covered with muslin cloth and secured firmly with rubber band. The cotton swab soaked in 5 per cent honey solution was kept suspended in the jar from the top as food for newly emerged adults. The freshly emerged moths were collected and ten pairs of freshly emerged male and female adult were confined individually into the glass jar. The inner side of glass jar was wrapped with black coloured paper to observe egg laying. The cotton swab soaked in 5 per cent honey solution was kept suspended in a glass jar as food for moths. The swab soaked in honey solution was changed daily. The twig of lablab bean along with tender buds and pods were kept in 250 $\mathrm{ml}$ conical flask with water. The mouth of conical flask was closed with cotton to avoid falling of moths into the water. It was done to provide host in natural condition for egg laying. Dates of pre-oviposition, oviposition and post oviposition period were recorded.

\section{Pre-oviposition period}

The period required from the emergence of female moth from pupa to the commencement of egg laying was recorded for ten females. 
On this basis, average pre-oviposition period was worked out.

\section{Oviposition period}

To work out the oviposition period, dates of first and last egg laid by female moth was recorded. The period between those two dates was considered as oviposition period. Such oviposition period was recorded for ten females and mean oviposition period was worked out.

\section{Post-oviposition period}

The period from cessation of oviposition by female moth till death was recorded for ten females. On this basis average postoviposition period was worked out.

\section{Site of oviposition}

Microscopic observations on the site of oviposition under captivity were made while working out the oviposition period. All the plant parts, paper surface, glass jar surface and muslin cloth were observed critically for the eggs.

\section{Fecundity}

To study the fecundity, total numbers of eggs laid by each female during its life span were counted. Such ten females were observed and mean fecundity was worked out.

\section{Egg morphometrics}

The morphometrics of eggs were recorded by using "computerized micrometer". The average length and breadth was recorded on the basis of ten eggs.

\section{Incubation period}

To study the incubation period, the number of days from egg laid till the hatching of egg was recorded as incubation period. A set of hundred eggs was kept under observation.

\section{Larval period, instars and morphometrics}

For this study, fifty petri plates containing single larva in each were kept in the laboratory and provided with fresh buds of lablab bean twice in a day. Further observations on larval instars and larval periods were recorded.

For recording larval instars, the larva in each plate was observed daily for moulting. The exuviae seen on bud or in petri plate indicated the change in the instar.

The number of moultings was determined on the basis of casted head capsule. The period between each moulting was recorded as period for corresponding instar. The duration of larval instars was recorded and described. The linear measurements on head width and body length were recorded using "computerized micrometer scale" for ten larvae. Thus, the data obtained were averaged out and presented.

\section{Pre-pupal period}

The period required from full development of larva as indicated by cessation of feeding till complete formation of pupa was recorded for ten larvae and average prepupal period was worked out and data are presented.

\section{Pupal period}

To record pupal period, ten freshly formed pupae were kept under observation in plastic jars till emergence of adult and on this basis the average pupal period was worked out.

The mean length and breadth of pupa were also recorded by using "millimeter scale" on the basis of measurements taken for ten pupae. 


\section{Adult longevity}

Newly emerged adults were separated for their sexes and released in a separate plastic jar and cotton swab soaked in five per cent honey solution was kept suspended in the jar as food for moth. To record the longevity of adult moths without food, ten newly emerged male and female moths were released in another jar without five per cent honey solution. The top of all the jars were covered with muslin cloth and secured firmly with rubber band. The longevity of ten males and ten females was recorded by observing the duration between emergence and the death of the adult. The data thus obtained were used to calculate average longevity of male and female moths with food as well as without food.

\section{Adult morphometrics}

The measurements on body width, body length and wing expanse were recorded by using "millimeter scale" for ten adults of both the sexes separately. The body width was recorded across the thorax while wing expanse was recorded by spreading the wings completely and measured horizontally. The data thus obtained were averaged out and presented.

\section{Sex ratio}

To calculate sex ratio hundred pupae obtained from the egg mass of a female were kept under observation separately. The adults emerged from them were separated according to their sexes and sex ratio was worked out on the basis of number of male and female adults emerged from the total number of pupae.

\section{Life cycle}

The total period for the completion of life cycle was worked out based on the duration of egg, larval, pre-pupal, pupal and adult stage.

\section{Results and Discussion}

The biology of pod borer $M$. vitrata was studied in the laboratory of the Department of Agricultural Entomology, College of Agriculture, Dapoli, Dist. Ratnagiri during the rabi season of 2012-2013. The results obtained are presented and discussed hereunder.

\section{Pre-oviposition, oviposition and post-} oviposition period

The pre-oviposition, oviposition and postoviposition period were recorded and the results are presented in table 1 .

It was revealed that the pre-oviposition period varied from 3 to 4 days with an average of 3.3 days. The oviposition period ranged between 2 to 4 days with an average 3.3 days. The post-oviposition period was recorded only for 1 to 2 days with a mean of 1.30 days.

These observations are in conformity with the findings of the Ramasubramanian and Sundarababu (1988) who reported that the Pre-oviposition, oviposition and postoviposition period of 2.7 and 3.9 days, on hyacinth bean. Vaidya (2008) also reported that pre-oviposition, oviposition and postoviposition period lasted for 3.30, 3.00 and 1.30 days, respectively.

\section{Fecundity}

The data recorded on fecundity of bean pod borer, $M$. vitrata revealed that the total number of eggs laid by female in her life span varied from 38 to 82 with an average of 61.6 (Table 1). The observations are in accordance with Karmarkar (2006) who reported that the female of $M$. vitrata laid 37 to 81 eggs and 
Vaidya (2008) who reported that the female of $M$. vitrata laid 35 to 81 eggs.

\section{Site of oviposition}

The female usually laid eggs on flower buds and tender pods singly or in groups of 2 to 3 . Eggs were also observed on the black coloured paper, which was wrapped on the inner side of glass jar as well as on muslin cloth that was used to close the mouth of glass jar.

The result are in conformity with the findings of the Sharma (1998) who reported that eggs are deposited on floral buds and flowers, leaves, terminal shoots and pods, and were usually deposited in batches of 2 to 16 .

Table.1 Pre-oviposition, oviposition, post-oviposition period and fecundity of $M$. vitrata

\begin{tabular}{|c|c|c|c|c|}
\hline $\begin{array}{c}\text { Sr. } \\
\text { No. }\end{array}$ & $\begin{array}{c}\text { Pre- } \\
\text { oviposition } \\
\text { period } \\
\text { (days) }\end{array}$ & $\begin{array}{c}\text { Oviposition } \\
\text { period } \\
\text { (days) }\end{array}$ & $\begin{array}{c}\text { Post- } \\
\text { oviposition } \\
\text { Period } \\
\text { (days) }\end{array}$ & Fecundity \\
\hline 1 & 3 & 3 & 1 & 68 \\
\hline 2 & 3 & 4 & 1 & 82 \\
\hline 3 & 4 & 3 & 1 & 72 \\
\hline 4 & 3 & 3 & 2 & 42 \\
\hline 5 & 3 & 4 & 2 & 67 \\
\hline 6 & 4 & 2 & 1 & 38 \\
\hline 7 & 3 & 4 & 1 & 70 \\
\hline 8 & 3 & 4 & 2 & 62 \\
\hline 9 & 3 & 3 & 1 & 60 \\
\hline 10 & 4 & 3 & 1 & 55 \\
\hline Range & $\mathbf{3 - 4}$ & $\mathbf{2 - 4}$ & $\mathbf{1 - 2}$ & $\mathbf{3 8 - 8 2}$ \\
\hline Mean & $\mathbf{3 . 3}$ & $\mathbf{3 . 3}$ & $\mathbf{1 . 3}$ & $\mathbf{6 1 . 6}$ \\
\hline
\end{tabular}

Table.2 Morphometrics of eggs of $M$. vitrata

\begin{tabular}{|c|c|c|}
\hline $\begin{array}{c}\text { Sr. } \\
\text { No. }\end{array}$ & Length (mm) & Breadth $(\mathbf{m m})$ \\
\hline 1 & 0.62 & 0.43 \\
\hline 2 & 0.63 & 0.42 \\
\hline 3 & 0.65 & 0.43 \\
\hline 4 & 0.64 & 0.43 \\
\hline 5 & 0.64 & 0.42 \\
\hline 6 & 0.61 & 0.41 \\
\hline 7 & 0.63 & 0.42 \\
\hline 8 & 0.64 & 0.43 \\
\hline 9 & 0.62 & 0.42 \\
\hline 10 & 0.65 & 0.43 \\
\hline Range & $\mathbf{0 . 6 1 - 0 . 6 5}$ & $\mathbf{0 . 4 1 - 0 . 4 3}$ \\
\hline Mean & $\mathbf{0 . 6 3}$ & $\mathbf{0 . 4 2}$ \\
\hline
\end{tabular}


Table.3 Incubation period and hatching percentage of $M$. vitrata

\begin{tabular}{|c|c|c|c|c|c|c|c|c|}
\hline \multirow{2}{*}{$\begin{array}{l}\text { Sr. } \\
\text { No. }\end{array}$} & \multirow{2}{*}{$\begin{array}{c}\text { No. of } \\
\text { eggs } \\
\text { observed }\end{array}$} & \multicolumn{4}{|c|}{ No. of eggs hatched (days) } & \multirow{2}{*}{$\begin{array}{c}\text { Total } \\
\text { eggs } \\
\text { hatched }\end{array}$} & \multirow{2}{*}{$\begin{array}{l}\text { Hatching } \\
\text { percentage }\end{array}$} & \multirow{2}{*}{$\begin{array}{c}\text { Average } \\
\text { incubation } \\
\text { period }\end{array}$} \\
\hline & & 1 & 2 & 3 & 4 & & & \\
\hline 1 & 10 & - & - & 4 & 4 & 8 & 80 & 3.5 \\
\hline 2 & 10 & - & - & 3 & 4 & 7 & 70 & 3.5 \\
\hline 3 & 10 & - & - & 5 & 3 & 8 & 80 & 3.5 \\
\hline 4 & 10 & - & - & 5 & 5 & 10 & 100 & 3.5 \\
\hline 5 & 10 & - & - & 6 & 2 & 8 & 80 & 3.5 \\
\hline 6 & 10 & - & - & 4 & 4 & 8 & 80 & 3.5 \\
\hline 7 & 10 & - & 3 & 3 & - & 6 & 60 & 3 \\
\hline 8 & 10 & - & 4 & 4 & - & 8 & 80 & 3 \\
\hline 9 & 10 & - & - & 3 & 4 & 7 & 70 & 3.5 \\
\hline 10 & 10 & - & - & 4 & 6 & 10 & 100 & 3.5 \\
\hline \multicolumn{6}{|c|}{ Range } & 6-10 & $60-100$ & 3-3.5 \\
\hline & & Mę & & & & 8 & 80 & 3.4 \\
\hline
\end{tabular}

Table.4 Larval development period of $M$. vitrata

\begin{tabular}{|c|c|c|c|c|c|c|}
\hline \multirow{2}{*}{ Sr. No. } & \multicolumn{5}{|c|}{ Duration of larval instar (days) } & \multirow{2}{*}{$\begin{array}{c}\text { Total larval } \\
\text { period (days) }\end{array}$} \\
\hline & I & II & III & IV & V & \\
\hline 1 & 2 & 2 & 3 & 2 & 3 & 12 \\
\hline 2 & 2 & 2 & 2 & 2 & 3 & 11 \\
\hline 3 & 2 & 2 & 2 & 3 & 3 & 12 \\
\hline 4 & 3 & 2 & 2 & 2 & 4 & 13 \\
\hline 5 & 3 & 2 & 2 & 2 & 3 & 12 \\
\hline 6 & 2 & 2 & 2 & 2 & 3 & 11 \\
\hline 7 & 2 & 2 & 3 & 3 & 3 & 13 \\
\hline 8 & 2 & 3 & 3 & 2 & 3 & 13 \\
\hline 9 & 2 & 2 & 2 & 2 & 4 & 12 \\
\hline 10 & 2 & 2 & 2 & 3 & 3 & 12 \\
\hline Range & $2-3$ & $2-3$ & $2-3$ & $2-3$ & $2-4$ & $11-13$ \\
\hline Mean & 2.2 & 2.1 & 2.3 & 2.3 & 3.2 & 12.1 \\
\hline
\end{tabular}

\section{Eggs}

The freshly laid eggs were oval and yellowish white or creamy white in colour and glued to the surface of bud (Plate II). The colour of the eggs changed gradually to white just before hatching. The eggs measured 0.61 to $0.65 \mathrm{~mm}$ in length with an average of $0.63 \mathrm{~mm}$ and 0.41 to $0.43 \mathrm{~mm}$ in breath with an average of $0.42 \mathrm{~mm}$ (Table 2).
The present findings regarding eggs of $M$. vitrata are in conformity with Panickar and Jhala (2007) who reported the colour of eggs was creamy white and average length of eggs ranged from 0.62 to $0.64 \mathrm{~mm}$ and 0.47 to 0.48 mm width.

Karmarkar (2006) reported that an egg measured on an average $0.58 \mathrm{~mm}$ in length and $0.38 \mathrm{~mm}$ in breadth. 


\section{Incubation period and hatching percentage}

The data on incubation period and hatching percentage are presented in table 3 . It was evident from the data that the incubation period ranged from 3 to 3.5 days with a mean of 3.40 days. Hatching percentage ranged from 60 per cent to 100 per cent with an average of 80 per cent.

Similar observations were recorded by Vaidya (2008) who reported that the incubation period varied from 3.0 to 3.5 days with mean of 3.40 days and with 80 per cent egg hatching. Chinnabhai et al., (2002) reported the incubation period of 3.14 days on green gram.

\section{Larval development}

During present studies, it was observed that there were five larval instars (Plate III). The observations on larval instars and larval period are given in table 4 . The development period of larvae ranged from 11 to 13 days with an average of 12.1 days. During this period larvae moulted four times.

The present observations are in close conformity with reports of Ramasubramanian and Babu (1988) who recorded larval period of 12.90 days on hyacinth bean. Chinnabhai et al., (2002) reported that the larval development was completed within 11.12 days on green gram. Taro et al., (2004) reported the larval period of 12.9 days at 24$27^{\circ} \mathrm{C}$ under 95 per cent relative humidity.

The overall response of all the thirty four lablab bean cultivars showed that the mean bud infestation ranged between 2.29 to 25.88 per cent. The cultivar DPLW-22 recorded lowest bud infestation of 2.29 per cent followed by DPLW-21 (3.83\%), DPLW-20 $(4.77 \%)$ and DPLW-33 (4.84\%). The cultivar Kelashi recorded highest bud infestation of 25.88 per cent.
The per cent pod infestation was considerably high as compared to bud damage of thirty four cultivars. It ranged between 9.02 to 46.30 per cent. The cultivar DPLW-7 recorded lowest pod damage of 9.02 per cent, whereas the cultivar DPLW-57 recorded highest pod damage of 46.30 per cent. The cultivar DPLW-14, DPLW-3, DPLW-20, DPLW-4 and DPLW-6 recorded 9.87, 14.25, 14.32, 14.69 and 15.81 per cent mean pod infestation, respectively.

The cultivar DPLW-63 recorded highest grain yield (3277.78 Kg ha-1) followed by DPLW9, DPLW-10, DPLW-21, DPLW-25, DPLW33, DPLW-34, DPLW-45, DPLW-50, DPLW-54 and DPLW-56 which recorded the grain yield between 3041.67 to $3222.22 \mathrm{Kg}$ $\mathrm{ha}^{-1}$.

From the result obtained, it can be interpreted that genotype DPLW-22 was found to be less infested by pod borer at bud stage which recorded lowest bud infestation of 2.29 per cent. The genotype DPLW-7 was found to be less infested at pod stage with 9.02 per cent of pod infestation.

\section{References}

Anonymous, 2011a. Commodity insight yearbook 2010-11. Submitted by ZPDK on Thu, 15/09/2011 - 20:35. http://agropedia.iitk.ac.in.

Anonymous, 2011b. Area, production, and productivity of major pulses, Ministry of Agriculture, Govt. of India. www.mcxindia.com/www.pwc.com/in/ en.

Anonymous, 2011c. Agriculture contingency plan for district Ratnagiri, Konkan Mahsul Vibhag. Dept. of Agriculture, Govt. of Maharashtra. www.indiatravelogue.com.

Anonymous, 2012. http://www.permalink to bean pod borer harassing mungbeans.

Parvathy, V., Sreedevi, K., Muralikrishna, K. 
and Prasanthi, L. 2011. Incidence of pod borers in field bean, Lablab purpureus $\mathrm{L}$. in unprotected conditions. Current Biotica, 5(1): 64-71.

Sunitha, V., 2006. Varietal screening and insecticidal evaluation aginst Maruca vitrata (Geyer) in pigeonpea. B.Sc. (Agri.) thesis (Unpublished), submitted to Acharya N.G. Ranga Agricultural University, Rajendranagar, Hyderabad,
Andhra Pradesh.

Vaidya, S.P., 2008. Biology and Evaluation of some newer insecticides against spotted pod borer, Maruca vitrata (Fabricus) (Lepidoptera: Crambidae) infesting cowpea. M. Sc. (Agri.) thesis (Unpublished), submitted to Dr. Balasaheb Sawant Konkan Krishi Vidyapeeth, Dapoli, Maharashtra.

\section{How to cite this article:}

Shinde, K.G., Kumud V. Naik, P.P. Raut, V.S. Desai and Mehendale, S.K. 2017. Biology of Pod Borer, Maruca vitrata (Geyer) Infesting Lablab Bean. Int.J.Curr.Microbiol.App.Sci. 6(9): 67-74. doi: https://doi.org/10.20546/ijcmas.2017.609.007 